\title{
Projektowanie opieki pielęgniarskiej pacjenta geriatrycznego mieszkającego w Domu Pomocy Społecznej z wykorzystaniem ICNP®
}

\section{Designing nursing care for a geriatric patient living in a Nursing Home using ICNP®}

NATALIA PAWLAK¹, ZUZANNA STRZĄSKA - KLIŚ1, LENA SERAFIN¹, BOŻENA CZARKOWSKA-PĄCZEK ${ }^{1}$

${ }^{1}$ Studenckie Koło Naukowe Pielęgniarstwa Klinicznego, Wydział Nauki o Zdrowiu, Warszawskiego Uniwersytetu Medycznego

DOI: http://dx.doi.org/10.21784/IwP.2019.017

ISSN: 2451-1846

\section{Streszczenie:}

Wstęp. Według teorii Liliane Israel, starzenie się można określić jako działanie czasu na osobę [1]. Na przebieg czasu i nadchodzący okres starości nie mamy wpływu, jednak możemy sprawić, aby czas ten był okresem godnej starości. Wiele osób doświadcza pojawiających się problemów z pamięcią, zmniejszenia wydolności i odporności na wysiłek fizyczny, pogorszenia słuchu i wzroku czy spadku elastyczności skóry. Należy pamiętać, że na proces ten składają się czynniki biologiczne, psychologiczne oraz środowiskowe. Prognozy demograficzne wskazują na stopniowe starzenie się społeczeństwa; coraz częściej będziemy stykać się z osobami powyżej 90. roku życia. Polska obecnie staje przed dużym wyzwaniem - nie tylko medycznym, lecz również o charakterze ekonomicznym czy społecznym.

Cel pracy. Celem pracy jest określenie zadań pielęgniarki w opiece nad pacjentem geriatrycznym mieszkającego w Domu Pomocy Społecznej, z wykorzystaniem klasyfikacji ICNP®.

Prezentacja przypadku. Pacjentka 91 lat, zakwalifikowana do DPS na podstawie oceny sprawności ruchowej za pomocą Międzynarodowej skali Barthel. Pacjentka uskarża się na problemy z koncentracją oraz pamięcią. 
W związku z nabytą u pacjentki cukrzycą typu II stosuje się do diety lekkostrawnej. Zgłasza uczucie duszności, wynikające z przewlekłej obturacyjnej choroby płuc (POChP), którą potęguje sporadyczne palenie tytoniu. Z wywiadu w roku 2012 pacjentka przebyła zabieg implantacji układu stymulującego serca z uwagi na zespół tachykardia - bradykardia. W dokumentacji medycznej odnotowano informację o III stadium choroby nerek oraz nawracającym zakażeniu układu moczowego.

Wnioski. Proces starzenia jest poddawany ciągłej obserwacji i badaniom, aby ocenić przyczyny jego rozpoczęcia i przebiegania. Jest od jednak nieunikniony. Projektowanie opieki nad pacjentem geriatrycznym z zastosowaniem klasyfikacji ICNP® daje możliwość nadania opiece wieloaspektowości oraz stworzeniu profilu pielęgniarki - specjalisty, z zakresu kompetencji takich jak dziedziny internistyczne czy geriatryczne.

Słowa kluczowe: geriatria, pacjent geriatryczny, dom pomocy społecznej, proces pielęgnowania, ICNP ${ }^{\circledR}$

\begin{abstract}
:
Introduction. According to the theory of Liliane Israel, aging can be defined as the impact of time on people [1]. We cannot influence the course of time and the upcoming period of old age, however, we can make this time a period of dignified ageing. Many people develop memory problems, reduced physical capacity and resistance to physical effort, reduced hearing and vision or decline in skin's elasticity. It should be remembered that biological, psychological and environmental factors comprise that process. Demographic outlook indicates gradual aging of the population; the number of people over 90 years old will more frequently arise. Poland is currently facing a major challenge - not only medical but also of an economic and social nature.

Aim of the study. The purpose of the study is to define the tasks of a nurse in caring for a geriatric patient living in a Nursing Home, using the ICNP $₫$ classification.
\end{abstract}

Case study. Woman, 91 years old, referred t DPS on the grounds of mobility assessment using the International Barthel scale. The patient complains about problems with concentration and memory. With regard to the patient's type II diabetes an easily digestible diet is applied. Patient reports 
breathing difficulty due to chronic obstructive pulmonary disease (COPD), which is incresed by occasional smoking. Medical history from 2012 shows that the patient underwent cardiac pacing implantation due to tachycardiabradycardia syndrome. It also showed stage III kidney disease and recurrent urinary tract infection.

Conclusions. The aging process is subject to constant observation and research in order assess the reasons for its beginning and course. However, it is inevitable. Designing care for a geriatric patient using the ICNP® classification allows us to give nursing care multidimentional status and create a profile of a nurse - a specialist in the field of internal medicine or geriatrics.

Keywords: geriatrics, geriatric patient, nursing home, nursing process, ICNP $^{\circledR}$

\section{Wstęp}

Według teorii Liliane Israel, starzenie się można określić jako naturalne działanie czasu na osobę [1]. Z uwagi na wartość średniej długości życia, szczególnie $w$ krajach rozwiniętych, starzenie się populacji jest obecnie zjawiskiem globalnym. Wiąże się ono ze zwiększonym ryzykiem rozwoju chorób przewlekłych, niepełnosprawnością fizyczną, zaburzeniami psychicznymi, zależnością od osób trzecich oraz wielochorobowością. Według definicji Światowej Organizacji Zdrowia, za osoby w wieku podeszłym uznaje się te, które ukończyły 65 rok życia [2]. Prognozy demograficzne na kolejne lata wskazują na wzrost liczby osób w wieku podeszłym. Sytuacja ta determinuje między innymi konieczność zwiększenia miejsc opieki instytucjonalnej dla osób starszych, w tym również miejsc $w$ Domach Pomocy Społecznej (DPS) [3]. DPS świadczy usługi bytowe, wspomagające, opiekuńcze oraz edukacyjne osobom wymagającym całodobowej opieki wynikającej z wieku, niepełnosprawności oraz choroby [3]. Zainteresowanie osób starszych pomocą publicznych instytucji opiekuńczych może wynikać m.in. ze względu na spadek zainteresowania rodziny oraz różnicą 
międzypokoleniową wprowadzającą napięcie $\mathrm{w}$ relacjach z bliskimi [4].

Starzenie stanowi wyjątkowe wyzwanie dla wszystkich grup społecznych [2]. Potrzeby zdrowotne oraz problemy zdrowotne osób starszych muszą być rozpatrywane równolegle [5]. Problemy geriatryczne, do których warto się odnieść to depresja, nietrzymanie moczu oraz stolca, upadki oraz zaburzenia koordynacji ruchowej, zaburzenia słuchu i wzroku, otępienie oraz odleżyny. Do występowania tych problemów przyczyniają się także przewlekłe oraz ostre stany chorobowe [6].

Ważnym aspektem opieki nad pacjentem geriatrycznym jest Kompleksowa ocena geriatryczna (z ang. Comprehensive Geriatric Assessment - CGA) definiowana jako wielowymiarowy, multidyscyplinarny proces, który identyfikuje potrzeby medyczne, społeczne oraz funkcjonalne, co pozwala na tworzenie planu opieki w celu zaspokojenia potrzeb osoby w wieku podeszłym [7]. CGA jest skuteczna oraz niezbędna $w$ ocenie funkcjonowania osób starszych w warunkach szpitalnych, zakładach opiekuńczo - leczniczych jaki i domowych. CGA jest także narzędziem wykorzystywanym w planowaniu działań zwiększających prawdopodobieństwo życia $\mathrm{w}$ domu oraz uniknięcia opieki instytucjonalnej oraz śmierci [7].

Bardzo ważnym elementem kształcenia pielęgniarek jest opieka skoncentrowana na osobach w wieku podeszłym. Program studiów przewiduje kompleksowe przygotowanie w tym zakresie. Uwzględnia ono m.in. wiedzę potrzebną do rozpoznawania problemów chorego oraz zaplanowania interwencji pielęgniarskich, umiejętności z zakresu komunikacji z pacjentem geriatrycznym i jego bliskimi oraz empatię i zrozumienie [6].

Starzejące się społeczeństwo staje się wyzwaniem dla systemu opieki zdrowotnej za względu długoterminowy charakter opieki oraz koszty z nią związane powodując potrzebę rozwoju nowych strategii 
opieki w celu zaspokojenia szczególnych wymagań osób starszych oraz ich rodzin [2].

\section{Cel}

Celem pracy jest zaplanowanie opieki pielęgniarskiej nad pacjentem geriatrycznym mieszkającym w DPS poprzez opracowanie diagnoz oraz interwencji. W planowaniu opieki pielęgniarskiej bazowano na tradycyjnym modelu procesu pielęgnowania, który rozszerzono o opracowanie w oparciu o Międzynarodową Klasyfikację Praktyki Pielęgniarskiej ICNP ${ }^{\circledR}$.

\section{Materiał i metody:}

Praca została przygotowana $\mathrm{z}$ zastosowaniem metody indywidualnego przypadku; do jej opracowania wykorzystano następujące techniki zbierania danych: wywiad bezpośredni, obserwacja chorego, analiza dokumentacji medycznej (historii choroby, wyników badań, karty gorączkowej, karty indywidualnej opieki pielęgniarskiej), pomiar podstawowych parametrów życiowych (tętno, ciśnienie tętnicze krwi, częstość oddechów, temperatura ciała). Badanie, przeprowadzono w kwietniu 2018 r., a na jego realizację otrzymano zgodę kierownictwa DPS, w którym mieszkała pacjentka. $\mathrm{Na}$ podstawie zebranych informacji postawiono diagnozy pielęgniarskie oraz sformułowano indywidualny plan opieki pielęgniarskiej z zastosowaniem klasyfikacji ICNP ${ }^{\circledR}$.

\section{Prezentacja przypadku}

Pacjentka, lat 91, urodzona w Warszawie. Ma dwoje dzieci: córkę oraz syna, którzy na stałe mieszkają poza granicami kraju. Ze względu na samotność oraz problemy w wykonywaniu czynności dnia codziennego pacjentka zdecydowała się na pobyt stały w DPS (od 2010roku). Przy przyjęciu do DPS stan chorej pod kątem sprawności ruchowej został oceniony przy użyciu Międzynarodowej Skali Barthel, w której uzyskała 75/100 punktów, co wskazuje 
na "lekki” stan pacjenta [8]. Mąż pacjentki zmarł w roku 2009, chora otrzymuje po nim emeryturę.

W wywiadzie pacjentka zgłasza duszność. Jednym z powodów jest przewlekła obturacyjna choroba płuc (POChP), rozpoznana w roku 2010, którą nasila sporadyczne palenie tytoniu. W roku 2012 pacjentka przebyła zabieg implantacji układu stymulującego serca z uwagi na zespół tachykardia - bradykardia. Jest pod stałą kontrolą kardiologa. W dokumentacji medycznej odnotowano informację o III stadium przewlekłej choroby nerek oraz nawracającym zakażeniu układu moczowego. Chora $\mathrm{z}$ zgłasza dolegliwości bólowe układu kostno-stawowego, w szczególności w obszarze stawów dłoni, nadgarstków, łokci i kolan. Ból ocenia na 4 na skali VAS. Przyczyną dolegliwości jest reumatoidalne zapalenie stawów.

W związku ze zdiagnozowaną u pacjentki cukrzycą typu II, stosuje dietę cukrzycową, którą samodzielnie modyfikuje bez konsultacji $\mathrm{z}$ dietetykiem. Pacjentka zgłasza problemy z koncentracją uwagi oraz pamięcią. Przypomina sobie tylko wybiórcze sytuacje $\mathrm{z}$ życia codziennego.

W tabeli 1. Zaprezentowano szczegółowe informacje o chorej oraz wyniki badania podmiotowego.

Tabela 1. Arkusz indywidualnego opisu przypadku opracowanie na podstawie Lesińska-Sawicka M (2009) [9].

\begin{tabular}{ll}
\hline DANE SOCJODEMOGRAFICZNE & \\
\hline Rok urodzenia: $12.10 .1928 \mathrm{r}$. & Płeć: Kobieta \\
Stan cywilny: wdowa & Wykonywany zawód: emerytka \\
& \\
\hline STAN OGÓLNY (podczas zbierania wywiadu) & \\
\hline Temperatura: $36.2^{\circ} \mathrm{C}$ & \\
Tętno (liczba/napięcie $/ \mathrm{rytm}$ ): $62 \mathrm{ud} / \mathrm{min}$, dobrze napięte, miarowe \\
Oddechy: 18 oddechów $/ \mathrm{min}$ & \\
Ciśnienie tętnicze: $132 / 75 \mathrm{mmHg}$ & \\
Masa ciała: $56 \mathrm{~kg}$ & \\
Wzrost: $1,55 \mathrm{~m}$ &
\end{tabular}




\begin{tabular}{l}
\hline WYWIAD RODZINNY \\
\hline Członkowie rodziny: córka (66lat), syn (70lat) \\
Ważne wydarzenia w rodzinie - ostatnie lata: nie podaje \\
Choroby występujące w rodzinie: nadciśnienie tętnicze, cukrzyca, \\
niedoczynność tarczycy, zaćma, rak piersi, choroba wieńcowa \\
Hobby/ zainteresowania: szydełkowanie, gra w scrabble, rozwiązywanie \\
krzyżówek \\
Formy spędzania czasu wolnego: spacery, spędzanie czasu z \\
współmieszkańcami DPS-u \\
Nałogi w rodzinie: palenie tytoniu, alkoholizm \\
Błędy żywieniowe (jakościowe i ilościowe): pacjentka ogranicza spożywanie \\
produktów odzwierzęcych bez ustaleń dietetycznych. \\
psychiczne/fizyczne: w stanie dobrym \\
Ograniczone kontakty/brak wsparcia społecznego: nie dotyczy
\end{tabular}

Źródło: wyniki badań własnych 
Tabela 2. Badanie fizykalne - opracowanie na podstawie LesińskaSawicka M (2009) [4].

\begin{tabular}{|c|c|c|c|c|c|}
\hline \multicolumn{6}{|c|}{ UKŁAD ODDECHOWY } \\
\hline Liczba & \multicolumn{2}{|c|}{ Typ oddechu } & \multicolumn{2}{|c|}{ Kaszel } & Inne objawy \\
\hline 18oddechów/min & \multicolumn{2}{|c|}{$\begin{array}{l}\text { Miarowy/przyspieszony } \\
\text { zależny od wysiłku } \\
\text { fizycznego }\end{array}$} & \multicolumn{2}{|c|}{ Nie dotyczy } & Duszność \\
\hline \multicolumn{6}{|c|}{ UKŁAD KRĄŻENIA } \\
\hline Ciśnienie & Tętno & \multicolumn{2}{|c|}{ Sinica } & Obrzęki & Duszność \\
\hline $132 / 75 \mathrm{mmHg}$ & $62 \mathrm{ud} / \mathrm{min}$ & \multicolumn{2}{|c|}{ Nie dotyczy } & $\begin{array}{l}\text { Kończyn } \\
\text { dolnych }\end{array}$ & $\begin{array}{c}\text { Przy } \\
\text { nadmiernym } \\
\text { wysiłku } \\
\text { fizycznym }\end{array}$ \\
\hline \multicolumn{6}{|c|}{ UKŁAD POKARMOWY } \\
\hline Uzębienie & Laknienie & \multicolumn{2}{|c|}{ Stolec } & Dieta & Inne \\
\hline $\begin{array}{l}\text { Proteza zębowa } \\
\text { górna i dolna }\end{array}$ & Prawidłowe & \multicolumn{2}{|c|}{ Prawidłowy } & $\begin{array}{l}\text { Cukrzycowa, } \\
\text { lekkostrawna }\end{array}$ & Nie dotyczy \\
\hline \multicolumn{6}{|c|}{ UKŁAD MOCZOWY } \\
\hline Objętość moczu & \multicolumn{2}{|c|}{ Jakość } & \multicolumn{2}{|c|}{ Inne objawy } & $\begin{array}{l}\text { Wyroby } \\
\text { medyczne }\end{array}$ \\
\hline $\begin{array}{c}\text { Trudny do } \\
\text { określenia } \\
\text { pacjentka } \\
\text { aktywna (4-6 } \\
\text { mikcji na dobę) }\end{array}$ & \multicolumn{2}{|c|}{ Barwy słomkowej } & \multicolumn{2}{|c|}{$\begin{array}{l}\text { Nietrzymanie } \\
\text { moczu }\end{array}$} & Pieluchomajtki \\
\hline \multicolumn{6}{|c|}{ UKŁAD PŁCIOWY } \\
\hline \multicolumn{3}{|c|}{ Cykl płciowy } & \multicolumn{3}{|c|}{ Inne cechy } \\
\hline \multicolumn{3}{|c|}{ Adekwatny do wieku } & \multicolumn{3}{|c|}{ Nie dotyczy } \\
\hline \multicolumn{6}{|c|}{ UKŁAD NERWOWY } \\
\hline $\begin{array}{c}\text { Świadomość wg } \\
\text { skali Glasgow }\end{array}$ & \multicolumn{2}{|c|}{ Niedowład/drżenia } & \multicolumn{2}{|r|}{ Mowa } & Inne objawy \\
\hline 15pkt łagodnie & \multicolumn{2}{|c|}{ Nie dotyczy } & \multicolumn{2}{|c|}{ Brak zaburzeń } & $\begin{array}{l}\text { Otępienie } \\
\text { starcze }\end{array}$ \\
\hline
\end{tabular}

Źródło: wyniki badań własnych 


\section{Diagnozy $i$ interwencje pielęgniarskie}

Po przeprowadzonym badaniu podmiotowym i przedmiotowym zdiagnozowano u pacjentki następujące problemy pielęgnacyjne: duszność nasilająca się podczas wysiłku, co znacznie utrudnia chorej samoopiekę, zawroty głowy występujące na skutek częstych zmian wartości ciśnienia tętniczego krwi, nietrzymanie moczu, dolegliwości bólowe stawów wynikające $\mathrm{z}$ choroby reumatycznej, zaburzenia funkcji poznawczych, kłopoty z pamięcią świeżą spowodowane otępieniem starczym.

Poniżej przedstawiono plan opieki pielęgniarskiej nad pacjentką w odniesieniu do zdiagnozowanych problemów pielęgnacyjnych z wykorzystaniem Międzynarodowej Klasyfikacji Praktyki Pielęgniarskiej ICNP® (Tabela 3.)

Opieka została zaplanowana i zrealizowana w oparciu o modele Virginii Henderson i Callisty Roy.

Poniżej, w Tabeli 3., zaprezentowano najważniejsze problemy pielęgnacyjne opisywanego chorego w sposób tradycyjny oraz z wykorzystaniem ICNP ${ }^{\circledR}$.

Tabela 3. Proces pielęgnowania pacjenta geriatrycznego mieszkającego w Domu Pomocy Społecznej z wykorzystaniem ICNP ${ }^{\circledR}$.

\begin{tabular}{|c|c|}
\hline Problem pielęgnacyjny I & $\begin{array}{l}\text { Diagnoza negatywna }(+ \text { kod } \\
\left.\text { ICNP }^{\circledR}\right)\end{array}$ \\
\hline Duszność wysiłkowa & $\begin{array}{l}\text { Duszność funkcjonalna } \\
\text { (wysiłkowa) [10029141] }\end{array}$ \\
\hline $\begin{array}{l}\text { Cel planowanych działań } \\
\text { pielęgniarskich: }\end{array}$ & Zmniejszenie dolegliwości \\
\hline $\begin{array}{l}\text { Planowane interwencje } \\
\text { pielęgniarskie: }\end{array}$ & $\begin{array}{l}\text { Interwencje pielęgniarskie } \\
\text { ICNP }{ }^{\circledR}:\end{array}$ \\
\hline $\begin{array}{l}\text { - ocena charakteru, stopnia nasilenia } \\
\text { duszności oraz czynników wywołujących } \\
\text { tę dolegliwość }\end{array}$ & $\begin{array}{l}\text { - ocenianie akceptacji stanu } \\
\text { zdrowia [10026249]; -ocena } \\
\text { stopnia samodzielności }\end{array}$ \\
\hline
\end{tabular}




\begin{tabular}{|c|c|}
\hline ych & $\begin{array}{l}\text { [10002723]; -ocenianie } \\
\text { zmęczenia [10026086] - } \\
\text { ocenianie zdolności do } \\
\text { zarządzania stresem } \\
\text { [10044130] } \\
\text { - ocenianie stanu oddechowego } \\
\text { [10036786] + termin z osi P: } \\
\text { duszność funkcjonalna } \\
\text { (wysiłkowa) [10008268] } \\
\text { - ocenianie warunków } \\
\text { mieszkaniowych [10030625] + } \\
\text { termin z osi Ś: nawilżacz } \\
\text { [10009228] + termin z osi P: } \\
\text { temperatura [10019556] } \\
\text { - nauczanie o ćwiczeniach } \\
\text { [10040125] + termin z osi Ś: } \\
\text { ćwiczenia oddechowe } \\
\text { [10004221] } \\
\text {-promowanie samoopieki } \\
\text { [10026347] } \\
\text {-nauczanie o ćwiczeniach } \\
\text { [10040125]; -nauczanie o } \\
\text { sposobie zwiększania tolerancji } \\
\text { aktywności ruchowej } \\
\text { [10024660] } \\
\text { - nauczanie o prewencji } \\
\text { upadków [10040253]; - } \\
\text { demonstrowanie metod } \\
\text { prewencji upadków [10040248] } \\
\text { Terapia z wykorzystaniem } \\
\text { urządzenia wspomagającego } \\
\text { [10039158]. }\end{array}$ \\
\hline $\begin{array}{l}\text { Ocena realizowanych działań } \\
\text { pielęgniarskich: Duszność wysiłko } \\
\text { zmniejszyła się }\end{array}$ & $\begin{array}{l}\text { Diagnoza } \\
\text { pozytywna/negatywna ICNP }{ }^{\circledR} \text { : } \\
\text { Bez duszności [10029164] }\end{array}$ \\
\hline
\end{tabular}




\begin{tabular}{|c|c|}
\hline \multicolumn{2}{|c|}{$\begin{array}{l}\text { Działanie opiera się na próbie nauczenia pacjentki efektywnych ćwiczeń } \\
\text { oddechowych, które w znaczący sposób zredukują dolegliwości związane z } \\
\text { dusznością podczas aktywności, a to nada pacjentce większe poczucie } \\
\text { samodzielności oraz możliwości spełniania potrzeb biologicznych, } \\
\text { fizycznych i społecznych. }\end{array}$} \\
\hline Problem pielęgnacyjny II & $\begin{array}{l}\text { Diagnoza negatywna (+kod } \\
\text { ICNP }^{\circledR} \text { ) }\end{array}$ \\
\hline $\begin{array}{l}\text { Zawroty głowy występujące na skutek } \\
\text { częstych zmian wartości ciśnienia } \\
\text { tętniczego krwi. }\end{array}$ & Zawroty głowy [10045584] \\
\hline $\begin{array}{l}\text { Cel planowanych działań } \\
\text { pielęgniarskich: }\end{array}$ & $\begin{array}{l}\text { Zmniejszenie częstości } \\
\text { występowanie zawrotów głowy } \\
\text { oraz zmian wartości ciśnienia } \\
\text { tętniczego. }\end{array}$ \\
\hline $\begin{array}{l}\text { Planowane interwencje } \\
\text { pielęgniarskie: }\end{array}$ & $\begin{array}{l}\text { Interwencje pielęgniarskie } \\
\text { ICNP }^{\circledR}:\end{array}$ \\
\hline $\begin{array}{l}\text { - monitorowanie układu krążenia m.in. } \\
\text { codzienne pomiary podstawowych } \\
\text { parametrów tj. ciśnienia tętniczego, tętna, } \\
\text { saturacji; } \\
\text { - niwelowanie czynników nasilający } \\
\text { deficyt tlenowy współistniejący z } \\
\text { zawrotami głowy, m.in. ułożenie } \\
\text { pacjentki w pozycji wysokiej, nauczanie o } \\
\text { tlenoterapii; } \\
\text { - zredukowanie napięcia emocjonalnego; } \\
\text { - podaż środków farmakologicznych } \\
\text { zgodnie ze zleceniem; } \\
\text { - edukacja pacjentki pod kątem } \\
\text { regularnych pomiarów ciśnienia oraz } \\
\text { przyjmowania stałych zleconych leków } \\
\text { na nadciśnienie tętnicze; } \\
\text { - edukacja w zakresie obserwowania oraz } \\
\text { identyfikowania sytuacji, w których } \\
\text { dolegliwości występują i/lub nasilają się; } \\
\text { - redukcja lęku oraz napięcia }\end{array}$ & $\begin{array}{l}\text { - monitorowanie ciśnienia krwi } \\
\text { [10032052] } \\
\text {-pozycjonowanie pacjenta } \\
\text { [10014761] } \\
\text { - nauczanie o tlenoterapii } \\
\text { [10044786] } \\
\text { - zarządzanie negatywnymi } \\
\text { emocjami [10031851] } \\
\text { - administrowanie lekiem } \\
\text { [10025444] } \\
\text {-nauczanie o pomiarze ciśnienia } \\
\text { krwi [10044148] } \\
\text { - nauczanie o podawaniu leku } \\
\text { [10040712] } \\
\text { - używanie (wykorzystywanie) } \\
\text { technik obniżania napięcia } \\
\text { [10036202] }\end{array}$ \\
\hline
\end{tabular}




\begin{tabular}{|c|c|}
\hline mocjonaln & \\
\hline $\begin{array}{l}\text { Ocena realizowanych działań } \\
\text { pielęgniarskich: Częstość zawrotów } \\
\text { głowy zminimalizowano }\end{array}$ & $\begin{array}{l}\text { Diagnoza } \\
\text { pozytywna/negatywna ICNP }{ }^{\circledR} \text { : } \\
\text { Bez zawrotów głowy } \\
{[10045681]}\end{array}$ \\
\hline Uzasadnienie planowanej interwencji & elęgniarskiej: \\
\hline $\begin{array}{l}\text { Zawroty głowy u pacjentów geriatryczny } \\
\text { względu na ogólne pogorszenie sprawno } \\
\text { samodzielności. Podobnie, jak w przypad } \\
\text { przyczyny układowych i nieukładowych } \\
\text { podeszłym wieku należy wnikliwie anali } \\
\text { mających na celu zminimalizowanie ryzy } \\
\text { [10]. }\end{array}$ & $\begin{array}{l}\text { tanowią istotny problem ze } \\
\text { raz ograniczenie } \\
\text { nnych grup wiekowych, } \\
\text { rotów głowy u osób w } \\
\text { ać oraz dokonywać działań } \\
\text { ądź całkowite ich usunięcie }\end{array}$ \\
\hline Problem pielęgnacyjny III & $\begin{array}{l}\text { Diagnoza negatywna (+kod } \\
\text { ICNP }^{\circledR} \text { ) }\end{array}$ \\
\hline Nietr & $\begin{array}{l}\text { Nietrzymanie moczu } \\
{[10025686]}\end{array}$ \\
\hline $\begin{array}{l}\text { Cel planowanych działań } \\
\text { pielęgniarskich: }\end{array}$ & $\begin{array}{l}\text { Zmniejszenie dolegliwości } \\
\text { nietrzymania moczu }\end{array}$ \\
\hline $\begin{array}{l}\text { Planowane interwencje } \\
\text { pielęgniarskie: }\end{array}$ & $\begin{array}{l}\text { Interwencje pielęgniarskie } \\
\text { ICNP }{ }^{\circledR} \text { : }\end{array}$ \\
\hline $\begin{array}{l}\text { - wywiad oraz ocena funkcjonalna } \\
\text { dolnych dróg moczowych oraz poziomu } \\
\text { zdolności poznawczych; } \\
\text { - omówienie z pacjentem oraz jego } \\
\text { rodziną metod leczenie nietrzymania } \\
\text { moczu, poddanie pacjentki } \\
\text { szczegółowemu badaniu geriatrycznemu; } \\
\text { - prowadzenie bilansu płynów; } \\
\text { - wprowadzenie technik kontrolowania } \\
\text { nietrzymania moczu tj. pomoc w } \\
\text { prowadzeniu dziennika mikcji (dziennika } \\
\text { funkcjonowania pęcherza moczowego) } \\
\text { poprzez odnotowywanie częstotliwości } \\
\text { mikcji; } \\
\text { - wprowadzenie programu ćwiczenia }\end{array}$ & $\begin{array}{l}\text {-ewaluacja statusu układu } \\
\text { moczowo - płciowego } \\
\text { [10034011] } \\
\text { - ocenianie trzymania moczu } \\
\text { [10030781] } \\
\text { - badanie fizykalne } \\
\text { [110032258] } \\
\text { - zarzadzanie nietrzymaniem } \\
\text { moczu [10035238] } \\
\text { - stosowanie treningu pęcherza } \\
\text { moczowego [10045219] } \\
\text { - monitorowanie tolerancji } \\
\text { aktywności ruchowej } \\
\text { [10036622] } \\
\text { - asystowanie w czynnościach }\end{array}$ \\
\hline
\end{tabular}




\begin{tabular}{|c|c|}
\hline $\begin{array}{l}\text { pęcherza moczowego; } \\
\text { - ocena stanu pacjentki pod kątem } \\
\text { możliwości samodzielnego korzystania z } \\
\text { toalety, tj. sprawności podnoszenia się z } \\
\text { krzesła lub łóżka, korzystania z urządzeń } \\
\text { pomocniczych m.in. laski, chodzika, } \\
\text { wózka; } \\
\text { - usunięcie barier środowiskowych } \\
\text { utrudniających dostęp do toalety w DPS; }\end{array}$ & toaletowych [10023631]. \\
\hline $\begin{array}{l}\text { Ocena realizowanych działań } \\
\text { pielęgniarskich: Nietrzymanie moczu } \\
\text { utrzymuje się. }\end{array}$ & $\begin{array}{l}\text { Diagnoza negatywna ICNP }{ }^{\circledR} \text { : } \\
\text { Zaburzone oddawanie moczu } \\
{[10021790] \text {. }}\end{array}$ \\
\hline \multicolumn{2}{|c|}{ Uzasadnienie planowanej interwencji pielęgniarskiej: } \\
\hline \multicolumn{2}{|c|}{$\begin{array}{l}\text { Nietrzymanie moczu jest problemem zarówno ze sfery zdrowotnej, jak } \\
\text { również społecznej. Osoby starsze z tego powodu oraz dyskomfortu i } \\
\text { skrępowania z nim związanych, zaczynają unikać relacji i kontaktu z } \\
\text { pozostałymi osobami, w obawie przed kompromitacją incydentem } \\
\text { inkontyngencji. }\end{array}$} \\
\hline Problem pielęgnacyjny IV & $\begin{array}{l}\text { Diagnoza negatywna (+kod } \\
\text { ICNP }^{\circledR} \text { ) }\end{array}$ \\
\hline $\begin{array}{l}\text { Dolegliwości bólowe stawów } \\
\text { spowodowane reumatoidalnym } \\
\text { zapaleniem stawów }\end{array}$ & $\begin{array}{l}\text { Ból [10023130] + termin z osi P: } \\
\text { układ mięśniowo szkieletowy } \\
\text { [10012344] }\end{array}$ \\
\hline $\begin{array}{l}\text { Cel planowanych działań } \\
\text { pielęgniarskich: }\end{array}$ & $\begin{array}{l}\text { Zmniejszenie dolegliwości } \\
\text { bólowych }\end{array}$ \\
\hline $\begin{array}{l}\text { Planowane interwencje } \\
\text { pielęgniarskie: }\end{array}$ & $\begin{array}{l}\text { Interwencje pielęgniarskie } \\
\text { ICNP }^{\circledR}:\end{array}$ \\
\hline $\begin{array}{l}\text { - ocena natężenia bólu przy użyciu skali } \\
\text { VAS (4/10), lokalizacji bólu, czasu } \\
\text { trwania i czynników wywołujących } \\
\text { dolegliwości; } \\
\text { - identyfikacja i ocena wcześniejszych } \\
\text { doświadczeń związanych z bólem oraz } \\
\text { metod stosowanych do zwalczania } \\
\text { dolegliwości bólowych; } \\
\text { - wyjaśnienie chorej przyczyny bólu oraz }\end{array}$ & $\begin{array}{l}\text {-ocenianie bólu [10026119] } \\
\text { - ocenianie wiedzy o } \\
\text { zarządzaniu bólem [10039041] } \\
\text { - ocenianie kontroli bólu } \\
\text { [10002710] } \\
\text { - nauczanie o bólu [10039115] } \\
\text { - monitorowanie bólu } \\
\text { [10038929] } \\
\text { - ewaluacja odpowiedzi na }\end{array}$ \\
\hline
\end{tabular}




\begin{tabular}{|c|c|}
\hline $\begin{array}{l}\text { jego wpływu na organizm; } \\
\text { - zredukowanie lub wyeliminowanie } \\
\text { czynników zwiększających ból - } \\
\text { nadmierna aktywność fizyczna; } \\
\text { - stosowanie niefarmakologicznych } \\
\text { metod leczenia bólu, tj. zadbanie o } \\
\text { zapewnienie ciepłego ubrania w } \\
\text { obszarach dolegliwości, zaproponowanie } \\
\text { chorej interakcji z innymi } \\
\text { pensjonariuszami, aktywizowanie do } \\
\text { wykonywania ulubionych czynności, } \\
\text { zadbanie o wypoczynek; } \\
\text { - podaż środków p/bólowych zgodnie ze } \\
\text { zleceniem lekarskim. }\end{array}$ & $\begin{array}{l}\text { zarządzanie bólem [10034053] } \\
\text { - administrowanie lekiem } \\
\text { przeciwbólowym [10023084] }\end{array}$ \\
\hline $\begin{array}{l}\text { Ocena realizowanych działań } \\
\text { pielęgniarskich: Dolegliwości bólowe } \\
\text { zmniejszyły się }\end{array}$ & $\begin{array}{l}\text { Diagnoza } \\
\text { pozytywna/negatywna ICNP }{ }^{\circledR} \text { : } \\
\text { Radzenie sobie z bólem } \\
{[10040749]}\end{array}$ \\
\hline \multicolumn{2}{|c|}{ Uzasadnienie planowanej interwencji pielęgniarskiej: } \\
\hline \multicolumn{2}{|c|}{$\begin{array}{l}\text { W celu efektywnej terapii przeciwbólowej należy regularnie dokonywać } \\
\text { oceny dolegliwości z uwzględnieniem natężenia, lokalizacji, czasu trwania } \\
\text { oraz charakteru bólu [11]. }\end{array}$} \\
\hline Problem pielęgnacyjny V & $\begin{array}{l}\text { Diagnoza negatywna (+kod } \\
\text { ICNP }^{\circledR} \text { ) }\end{array}$ \\
\hline $\begin{array}{l}\text { Zaburzenia funkcji poznawczych, kłopoty } \\
\text { z pamięcią świeżą spowodowane } \\
\text { otępieniem starczym. }\end{array}$ & $\begin{array}{l}\text { Zaburzone funkcje poznawcze } \\
\text { [10022321] }\end{array}$ \\
\hline $\begin{array}{l}\text { Cel planowanych działań } \\
\text { pielęgniarskich: }\end{array}$ & $\begin{array}{l}\text { Zmniejszenie zaburzeń funkcji } \\
\text { poznawczych }\end{array}$ \\
\hline $\begin{array}{l}\text { Planowane interwencje } \\
\text { pielęgniarskie: }\end{array}$ & $\begin{array}{l}\text { Interwencje pielęgniarskie } \\
\text { ICNP }{ }^{\circledR}:\end{array}$ \\
\hline $\begin{array}{l}\text { - ocena funkcji poznawczych; } \\
\text { - w sposób jasny i prosty wyjaśnianie } \\
\text { pacjentce na czym polegają zaburzenia } \\
\text { spowodowane otępieniem; } \\
\text { - edukacja opiekunów w zakresie }\end{array}$ & $\begin{array}{l}\text { - ocenianie funkcji poznawczych } \\
\text { [10025883] } \\
\text { - nauczanie o chorobie } \\
\text { [10024116] } \\
\text { - nauczanie technik }\end{array}$ \\
\hline
\end{tabular}


sprawowania opieki nad chorą: utrzymanie przyzwyczajeń/upodobań chorej, unikanie zmian w najbliższym otoczeniu, systematyczne utrwalanie podstawowych informacji dotyczących tożsamości chorego i jego rodziny, umieszczanie w pokojach napisów, rysunków, symboli, które ułatwią orientację;

- w każdej trudnej dla chorego sytuacji okazywanie życzliwości oraz wsparcia; -ocena reakcji na przeprowadzoną edukację.

\section{Ocena realizowanych działań}

pielęgniarskich: Funkcje poznawcze w granicach normy

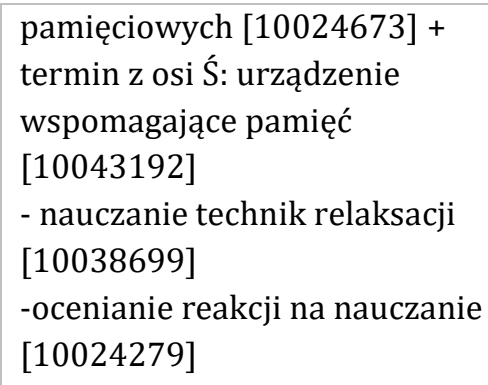

\section{Diagnoza \\ pozytywna/negatywna ICNP ${ }^{\circledR}$ :}

Funkcje poznawcze w granicach normy [10028367]

\section{Uzasadnienie planowanej interwencji pielęgniarskiej:}

Część zaburzeń poznawczych wiąże się z wiekiem i wpływa w sposób istotny na codzienne funkcjonowanie osoby starszej. Nazywane są one wtedy zaburzeniami związanymi z wiekiem. Osoba w podeszłym wieku często skarży się na gorsze funkcjonowanie w sytuacjach, gdy powinna podjąć szybką decyzję, przeanalizować znaczną ilość informacji lub wykonywać równolegle kilka różnych czynności.

\section{Dyskusja}

W planowaniu opieki pielęgniarskiej nad pacjentem geriatrycznym ważne jest przede wszystkim uwzględnienie procedur diagnostyczno-terapeutycznych $\mathrm{w}$ zakresie udzielania przez pielęgniarkę świadczeń zapobiegawczych, diagnostycznych, leczniczych i rehabilitacyjnych, zgodnie $\mathrm{z}$ przepisami Ustawy o zawodach pielęgniarki i położnej z dnia 15 lipca 2011 r. (Dz. U. 2011 $\mathrm{nr} 174$ poz. 1039) [12]. Działania te obejmują m.in. wywiad pielęgniarski, badanie przedmiotowe, ocenę sprawności funkcjonalnej w zakresie czynności życia codziennego przy użyciu 
Skali Oceny Podstawowych Czynności Życia Codziennego wg Katza (Activities of Daily Living - ADL) Skali Oceny Złożonych Czynności Życia Codziennego wg Lawtona (Instrumental Acitivites of Daily Living - IADL), Skali Barthel, ocenę stopnia nietrzymania moczu, planowanie procesu pielęgnacji, edukację $\mathrm{w}$ zakresie działań zwiększających komfort w wykonywaniu codziennych czynności, ograniczanie następstw niepełnosprawności przez aktywizację psychiczną i fizyczną $w$ procesie samoopieki oraz współpracę pielęgniarki $\mathrm{z}$ innymi członkami zespołu geriatrycznego [12]. Kompetencje te umożliwiają opracowanie zindywidualizowanego planu opieki nad pacjentem geriatrycznym wymagającym holistycznej opieki, z uwzględnieniem zarówno opieki w zakresie dolegliwości somatycznych, jak i psychospołecznych.

$\mathrm{W}$ wielu przypadkach osoby $\mathrm{w}$ wieku podeszłym pozostają pod opieką lekarza geriatry [13]. Często z racji zaawansowanego wieku oraz wielochorobowości pojawia się $\mathrm{u}$ nich ryzyko nagłego pogorszenia stanu zdrowia lub zgonu, a liczne objawy wymagają od pielęgniarki wnikliwej obserwacji oraz interwencji uwzględniającej opiekę holistyczną [13].

Dokonując analizy umiejętności pielęgniarskich niezbędnych do sprawowania opieki nad pacjentem geriatrycznym, stwierdzono, że ważną kompetencją jest efektywna komunikacja z pacjentem, często niesamodzielnym oraz niezdolnym do werbalizowania swoich potrzeb. Komunikacja z pacjentami geriatrycznymi może stanowić wyzwanie, które jednak warto podjąć, bowiem tylko dzięki temu można przeprowadzić wnikliwy wywiad i rozpocząć skuteczne leczenie i opiekę prowadzące do poprawy jakość jego życia. Brak efektywnej komunikacji może powodować u osób sprawujących opiekę poczucie bezradności, frustrację czy zniechęcenie, co w dłuższej perspektywie może skutkować wypaleniem zawodowym. Dlatego tak ważnym jest odpowiednie przygotowanie oraz stałe dokształcenie $\mathrm{w}$ zakresie sprawowanej opieki, dzięki czemu niezbędne kompetencje przyczynią 
się, nie tylko do poprawy jakości świadczeń i w efekcie lepszego stanu chorych, ale także poczucia komfortu pracy świadczeniodawców.

Jednym z najistotniejszych działań zwiększających efektywność w zakresie opieki pielęgniarskiej jest prowadzenie ujednoliconego procesu pielęgnacyjnego, celem wystandaryzowania pewnych czynności i postępowania [14]. Klasyfikacja problemów pielęgnacyjnych metodą ICNP ${ }^{\circledR}$ umożliwia między innymi uniwersalne monitorowanie liczby, charakteru czy jakości udzielanych świadczeń w jednostkowej analizie świadczeń pielęgniarskich, ale także w kontekście usług realizowanych w wielu ośrodkach z uwzględnieniem skali międzynarodowej.

\section{Wnioski}

Wstępna ocena stanu pacjenta, identyfikacja najważniejszych problemów oraz planowanie i podejmowanie interwencji w ramach zindywidualizowanego planu opieki pozwalają zarówno na poprawę stanu chorego, ale także zapewnienie bezpieczeństwa i poprawy jego jakości życia. Na podstawie postawionych diagnoz pielęgniarskich zaplanowano interwencje, z uwzględnieniem podejścia holistycznego na wszystkich etapach realizacji planu opieki. Opracowanie opieki pielęgniarskiej w oparciu o ICNP ${ }^{\circledR}$ umożliwia nie tylko monitorowanie ilości i jakości realizowanych świadczeń, ale również planowanie badań naukowych, co w efekcie wpływa na rozwój zarówno wystandaryzowanego pielęgniarstwa, jak również praktyki pielęgniarskiej opartej na dowodach naukowych.

\section{Bibliografia/Biblography:}

1. Zych A.A. Człowiek wobec starości - szkice z gerontologii społecznej. Wydawnictwo Śląskie. Warszawa 1993;45-50.

2. World Health Organization. The growing need for home health care for the elderly. Home health care for the elderly as an integral part of 
primary health care 2013. https://apps.who.int/iris/bitstream/handle/10665/326801/EMROPUB _2015_EN_1901.pdf?sequence=1\&isAllowed=y [data dostępu: 02.12.2019r.].

3. Nowak-Kapusta Z., Franek G., Leszczyńska K., Ćmiel-Giergielewicz M. Charakterystyka wybranych elementów sytuacji społecznozdrowotnej mieszkańców domów pomocy społecznej z uwzględnieniem występowania u nich objawów depresji. Gerontologia Polska 2017;25:511.

4. Traczyk J., Kędzia P., Skrzek A. Jakość życia, sprawność funkcjonalna oraz występowanie ryzyka depresji u kobiet po 60 roku życia mieszkających w domach opieki społecznej i samodzielne. Gerontologia Polska 2016;24:32-39.

5. Shrivastava SR., Shrivastava PS., Ramasamy J. Health-care of Elderly: Determinants, Needs and Services. Int J Prev Med. 2013;4(10):12241225.

6. Bieniek-Kamińska N., Fecko-Gałowicz K., Olchawa J. Wybrane wielkie problemy geriatryczne wśród mieszkańców przebywających w Domu Pomocy Społecznej w Mogilnie. Problemy pielęgniarstwa. 2017; 215220.

7. Parker S. G., Mcleod A., Mccue P. et. al. New Horizons in Comprehensive Geriatric Assessment. Age and Ageing 2017;46:713-721.

8. Karta oceny stanu zdrowia pacjenta wg zmodyfikowanej skali Barthel. Załącznik Nr 12 do zarządzenia Nr 69/2007/DSOZ z dnia 25 września 2007 r. Prezesa Narodowego Funduszu Zdrowia https://www.nfzlodz.pl/attachments/article/5719/Skala\%20Barthel.pdf [data dostępu: 03.12.2019r]

9. Lesińska-Sawicka M.(red.). Metoda Case Study w pielęgniarstwie. Borgis Wydawnictwo Medyczne. Warszawa 2009. 
10. Katsarkas A. Dizziness in aging: a retrospective study of 1194 cases. Otolaryngol Head Neck Surg. 1994;110(3):296-301.

11. Kaptacz A., Walden- Gałuszko K. Pielęgniarstwo opieki paliatywnej. Wydawnictwo Lekarskie PZWL. Warszawa 2016.

12. Ustawa z dnia 15 lipca 2011 r. o zawodach pielęgniarki i położnej. (Dz. U. $2011 \mathrm{nr} 174$ poz. 1039)

13. Wieczorkowska - Tobis K., Talarska D. Geriatria i pielęgniarstwo geriatryczne. Wydawnictwo Lekarskie PZWL. Warszawa 2015.

14. Derejczyk J., Grodzicki T., Jakrzewska - Sawińska A. Standardy świadczenia usług medycznych w specjalności geriatria. Gerontologia Polska 2003;13,(2):67-83.

Otrzymano: 09.12.2019r.

Zaakceptowano: 16.12.2019r. 
